\title{
QUALITY HERBAGE SEED - GERMINATION AND CONTAMINATION. 1. Ryegrass
}

\author{
J.G. HAMPTON and K.A. YOUNG \\ Official Seed Testing Station, MAF, Palmerston North
}

Keywords: seedlots, Lolium spp, germination, blind seed disease, heating damage, physical purity, weed seed contamination, seed certification.

New Zealand has long had a reputation for the quality of its herbage seed (Shillito, 1980). The basic responsibility for maintaining adequate seed quality control rests with the seed producers and industry personnel, allied with the role of MAF, which provides a means of impartially determining and verifying seed quality through a seed certification scheme and seed testing services.

Two of the important seed quality characteristics are those of germination and physical purity. This paper discusses aspects of these quality factors for New Zealand ryegrass seedlots from the 1982-84 harvests.

\section{Germination}

The laboratory germination of New Zealand ryegrass cultivars is usually high, with the majority of seedlots having a germination of $85 \%$ or greater (Hampton \& Scott, 1980). However, marked seasonal fluctuations occur. For example, in 1982, over $90 \%$ of all Grasslands Nui and Ellett perennial ryegrass seedlots tested had a germination of $90 \%$ or greater (Table 1), whereas in 1983 , only $65 \%$ of G. Nui and $74 \%$ of Ellett seedlots had a germination of $90 \%$ or greater. As well as seasonal fluctuation, germination results can also be influenced by the region of production (Table 2).

Table 1: PERCENTAGE OF GRASSLANDS NUI AND ELLETT PERENNIAL RYEGRASS SEEDLOTS' WITHIN EACH GERMINATION CATEGORY, 1982-84.

\begin{tabular}{lcccccc}
\hline $\begin{array}{l}\text { Germination } \\
\text { Category }\end{array}$ & \multicolumn{2}{c}{1992} & \multicolumn{2}{c}{1983} & \multicolumn{2}{c}{$1984^{2}$} \\
\hline$<70 \%$ & 0.6 & 1.5 & 3.6 & 6.0 & 0.0 & 2.7 \\
$70.79 \%$ & 0.3 & 1.3 & 3.9 & 7.6 & 1.3 & 7.5 \\
$80-89 \%$ & 4.5 & 6.1 & 18.2 & 21.9 & 13.2 & 28.8 \\
$90-100 \%$ & 94.6 & 91.1 & 74.3 & 64.5 & 85.5 & $61.0^{3}$ \\
Total Number & 332 & 1259 & 280 & 1027 & 227 & 333 \\
of seedlots & & & & & & \\
\hline
\end{tabular}

1 data are for official tests only, and do not include retests.

2 st January to 1 st June only.

3 Germination differences between Nui and Ellett are not cultivar related, but do reflect the influence of region of production (see Table 2).

Germination in a laboratory test is defined as the emergence and development from the seed embryo of those essential structures which, for the kind of seed being tested, indicate its ability to develop into a normal plant under favourable conditions in the soil (ISTA, 1976). A seed analysis certificate presents the percentage of seeds which have produced normal seedlings, the percentage of abnormal seedlings and the remainder (see Aglink FPP 828). In New Zealand low germination is more commonly associated with dead seeds than with abnormal seedlings. For example, in Table 3 , as the germination of Grasslands Moata tetraploid ryegrass seedlots decreased, the number of remainders increased. 
Table 2: INFLUENCE OF REGION OF PRODUCTION ON GERMINATION OF GRASSLANDS NUI PERENNIAL RYEGRASS, 1983 AND 1984.

\begin{tabular}{lccccc}
\hline & \multicolumn{2}{c}{$\begin{array}{c}\text { Percentage of seedlots within each } \\
\text { germination category, 1983 and 1984 }\end{array}$} & $\begin{array}{c}\text { Total number of } \\
\text { Region of }\end{array}$ \\
$\begin{array}{l}\text { Production } \\
\mathbf{< 7 0 \%}\end{array}$ & $\mathbf{7 0 - 7 9 \%}$ & $\mathbf{8 0 - 8 9 \%}$ & $\mathbf{> 9 0 \%}$ & \\
\hline $\mathbf{1 9 8 3}$ & & & & & 460 \\
Ashburton & 2.8 & 6.3 & 22.8 & 68.1 & 124 \\
Christchurch & 8.2 & 8.2 & 21.6 & 62.0 & 65 \\
Hawkes Bay & 0.0 & 3.0 & 7.6 & 89.4 & 125 \\
Manawatu & 16.0 & 16.0 & 41.6 & 26.4 & \\
1984' & & & & & 170 \\
Ashburton & 1.9 & 9.4 & 31.7 & 57.0 & 59 \\
Christchurch & 0.0 & 15.3 & 25.4 & 59.3 & 43 \\
Hawkes Bay & 0.0 & 0.0 & 9.4 & 90.6 & 64 \\
Manawatu & 3.1 & 7.8 & 32.8 & 56.3 & \\
\hline
\end{tabular}

1 1st January to 1 st June only

Table 3: MEAN PERCENTAGE GERMINATED SEED, ABNORMAL SEEDLINGS AND REMAINDERS WITHIN EACH GERMINATION CATEGORY, GRASSLANDS MOATA TETRAPLOID ITALIAN RYEGRASS, 1983.

\begin{tabular}{ccccc}
\hline $\begin{array}{c}\text { Germination } \\
\text { category }\end{array}$ & $\begin{array}{c}\text { Total number } \\
\text { of seedlots }\end{array}$ & Germination & $\begin{array}{c}\text { Mean percentage } \\
\text { Abnormal } \\
\text { seedlings }\end{array}$ & Remainder \\
\hline $\mathbf{2} 70 \%$ & 29 & 58.7 & 1.9 & 39.5 \\
$\mathbf{7 0 - 7 9 \%}$ & 6 & 75.8 & 1.6 & 22.6 \\
$\mathbf{8 0 - 8 9 \%}$ & 19 & 85.5 & 1.8 & 12.7 \\
$\mathbf{> 9 0 \%}$ & 38 & 92.6 & 1.2 & 6.2 \\
\hline
\end{tabular}

Dead seeds in ryegrass seedlots tested within a year of harvest result from one of three factors - (1) blind seed disease, caused by the fungus Gloeotinia temulenta (Prill and Del.) Wilson, Noble and Gray (see Hampton and Scott, 1980); (2) heating damage, resulting from the growth of storage fungi in seed stored incorrectly (Matthews and Hill, 1967); (3) the harvesting of immature seed. A small survey of 20 seedlots of G. Nui and 12 seedlots of Ellett perennial ryegrass from the 1983 harvest, all with germinations of less than $80 \%$, showed that 12 of the $\mathrm{G}$. Nui and three of the Ellett seedlots had blind seed disease (an average of $35 \%$ of seeds infected for both cultivars), seven of the G. Nui and nine of the Ellett seedlots had suffered heating damage, and one G. Nui seedlot contained a substantial quantity of immature seed.

Seasonal, region of production and cultivar germination differences in New Zealand ryegrass seedlots are often explained by the incidence of blind seed disease (Hampton and Scott, 1980), and by climatic conditions during harvest which may lead to storage problems. Further information on blind seed disease can be obtained from the Official Seed Testing Station, and on seed storage and drying from Aglinks FPP 832 and FPP 839.

\section{Physical Purity}

In a purity test a small but representative sample of a seedlot is separated into four components; pure seed of the species under test, other crop seeds, weed seeds, 
and inert matter. The percentage by weight of each component and the botanical name of the contaminating seeds are reported on a seed analysis certificate (see Aglink FPP828). Where the purity analysis is being carried out on a seedlot entered in the New Zealand certification scheme, final certification is only approved if the defined limits of contamination are not exceeded. (See Ag-Data "Seed Certification 1984").

The Official Seed Testing Station and the New Zealand Agricultural Merchants Federation recognise 14 weed species, which are considered to have serious weed potential, as particularly undesirable contaminants of seedlots (Table 4). The presence of any one of these undesirable species in a seedlot is highlighted on the seed analysis certificate by printing its common name alongside the botanical name. Table 4 indicates the percentage occurrence of these weeds in all officially sampled ryegrass lots during 1983. The eight species marked with an asterisk occur at low but regular levels in seedlots. The other six occur very infrequently indicating either their present occurrence in New Zealand is very limited, or they have seeds/which are readily dressed out (e.g. oxeye daisy, ragwort).

Table 4: OCCURRENCES OF UNDESIRABLE WEED SPECIES IN 4346 OFFICIALLY SAMPLED RYEGRASS' SEEDLOTS TESTED DURING 1963.

\begin{tabular}{llc}
\hline Botanicai Name & Common Name & \% Occurence \\
\hline Amsinckia calycina & yellow gromwell & 0.68 \\
'Avena fatua & wild oat & 4.89 \\
Cardaria draba & hoary cress & 0.00 \\
$\quad$ Carduus nutans & nodding thistle & 0.28 \\
*Carduus tenuiflorus & winged thistle & 1.36 \\
Cirsium arvense & Californian thistle & 0.21 \\
*Cirsium vulgare & Scotch thistle & 0.92 \\
*Conium maculatum & hemlock & 0.05 \\
Convolvulus arvensis & field bindweed & 0.00 \\
Cuscuta spp. & dodder & 0.00 \\
*Hordeum murinum & barley grass & 1.26 \\
Leucanthemum vulgare & oxeye daisy & 0.00 \\
Senecio jacobaea & ragwort & 0.00 \\
Stipa trichotoma & nasella tussock & 0.00 \\
\hline
\end{tabular}

* regularly occurring species

1 includes all ryegrass cultivars

Of the species marked with an asterisk, winged thistle, Californian thistle, Scotch thistle, hemlock and barley grass are wide-spread grassland weeds, but the remaining three (nodding thistle, wild oat, yellow gromwellj are still absent from many areas of New Zealand. Even in areas where they occur, individual properties may be free (e.g. wild oat; Allen and Butler, 1979). Contaminated seedlots are one way by which these species are spread.

Table 5 shows the percentage of officially sampled perennial ryegrass seed-lots contaminated by these undesirable weed species. Much of the contamination in the certified samples is due to winged thistle and the increase over the past three seasons is probably a reflection of successive dry summers favouring its growth.

Uncertified lots of perennial ryegrass (i.e. lots that were not entered in the certification scheme plus lots rejected from certification at laboratory analysis) are six times more likely to be contaminated with one of the 14 undesirable weeds than certified lots. 
Table 5: PERCENTAGE OF OFFICIALLY SAMPLED PERENNIAL RYEGRASS SEEDLOTS CONTAMINATED BY UNDESIRABLE WEEDS, 1982-1984.

\begin{tabular}{|c|c|c|c|c|c|c|}
\hline \multirow[b]{2}{*}{ Certified Seedlots } & \multicolumn{2}{|c|}{1982} & \multicolumn{2}{|c|}{1983} & \multicolumn{2}{|c|}{$1904^{\prime}$} \\
\hline & $\begin{array}{l}\text { No. } \\
\text { seedlots }\end{array}$ & $\begin{array}{c}\% \\
\text { contam. }\end{array}$ & $\begin{array}{c}\text { No. of } \\
\text { seedlots }\end{array}$ & $\begin{array}{c}\% \\
\text { contam. }\end{array}$ & $\begin{array}{c}\text { No. of } \\
\text { seedlots }\end{array}$ & $\begin{array}{c}\% \\
\text { contam. }\end{array}$ \\
\hline Ellett & 3 & 0.0 & 24 & 0.0 & 176 & 4.0 \\
\hline G. Nui & 1126 & 2.7 & 1027 & 3.3 & 333 & 6.0 \\
\hline G. Ruanui & 592 & 1.7 & 113 & 7.1 & 68 & 0.0 \\
\hline TOTAL & 1721 & 2.3 & 1164 & 3.6 & 577 & 4.7 \\
\hline \multicolumn{7}{|l|}{ Uncertified Seedlots } \\
\hline Ellett & 298 & 3.0 & $250^{2}$ & 9.2 & $40^{2}$ & 10.0 \\
\hline NZ Permanent Pasture & e 266 & 7.5 & 173 & 9.8 & 119 & 15.1 \\
\hline Perennial Ryearass $^{3}$ & 210 & 37.6 & 205 & 41.9 & 103 & 31.1 \\
\hline TOTAL & 774 & 14.0 & 628 & 20.1 & 262 & 20.6 \\
\hline
\end{tabular}

1 st January to 31 st May only

2 includes four seedlots rejected from certification

3 includes the following number of $G$. Nui and G. Ruanui seedlots rejected from certification:

1982: 42

1983: 65

1984: 20

Adherence to strict procedures and quality standards ensures that certified seed has a high physical purity. The risk of introducing serious weeds onto a producer's property is also considerably reduced through the use of certified seed.

\section{ACKNOWLEDGEMENTS}

Staff of the Official Seed Testing Station; MS S.F. Cane for technical assistance.

\section{REFERENCES}

Allen, F.C.; Butler, J.H.B. 1979. Proc 32nd NZ Weed and Pest Cont. Conf: 149-152. Hampton, J.G.; Scott, D.J. 1980. N.Z.J. agric Res., 23: 143-153.

International Seed Testing Association (ISTA) 1976. Seed Sci. and Technol. 4: 1-177 Matthews, B.D.; Hill, M.J. 1967. N.Z.J. Ag 774 (2): 25-27.

Shillito, N.L. 1980. In: Herbage Seed Production. Grassld Res and Pract. Series No. 1, NZ Grasslds Assn 1-3. 